\title{
Futebol em campo minado: representações da violência e da morte em "Cemitério clandestino", de Ana Paula Maia, e "Ademir", de Mariant Gallo
}

Football in Minefield: Representations of Violence and Death in "Cemitério Clandestino", by Ana Paula Maia, and "Ademir", by Mariant Gallo

Tânia Sarmento-Pantoja Universidade Federal do Pará (UFPA), Belém/Brasil Doutora em Estudos Literários, UNESP nicama@ufpa.br

\begin{abstract}
Resumo: Este estudo analisa os contos "Cemitério clandestino" e "Ademir", escritos pelos brasileiros Mariant Gallo e Ana Paula Maia. "Ademir" pertence à coletânea intitulada $O$ gol esquecido: contos de futebol (2014), que contém contos de Gallo, todos dedicados ao futebol, enquanto "Cemitério clandestino" pode ser encontrado em Entre as quatro linhas: contos sobre futebol (2013), coletânea organizada por Luiz Ruffato, que reúne quinze contistas. Dois aspectos, presentes em ambos os contos, movimentam a análise: o futebol e a violência.
\end{abstract}

PaLAVRAS-CHAVE: Literatura; Futebol; Violência; Resistência.

ABSTRACT: This study analyzes the tales "Cemitério Clandestino" and "Ademir", respectively written by Brazilians writers Mariant Gallo and Ana Paula Maia. "Ademir" belongs to the compilation entitled $O$ gol esquecido (2014), which contains Gallo's tales, all dedicated to football, while "Cemitério Clandestino" can be found in Entre as quatro linhas: contos sobre futebol (2013), compiled by Luiz Ruffato, which brings together fifteen short story writers. Two aspects, present in both tales, move the analysis: football and violence.

KEYWORDS: Literature; Football; Violence; Resistance. 


\section{INTRODUÇÃo}

0 conto "Ademir" pertence à coletânea $O$ gol esquecido: contos de futebol, o décimo terceiro livro de Mariant Gallo, que reúne 21 contos, todos atravessados por temáticas direcionadas ao futebol. Ademir é o nome do protagonista. Ele é um talentoso jogador de futebol que inicialmente joga em um time de rua, na cidade de Caldeira, no interior do Rio de Janeiro. Mas, logo, Ademir galga a profissionalização ao ser contratado por um time pequeno, quando passa a ser considerado um craque por todos os que o conheciam em sua cidade de origem, com seu talento e garra refletidos em uma frase marcante: “- Ninguém para esse cara!”. ${ }^{1}$

Além de ser apaixonado por futebol e de se dedicar às competições, Ademir gosta de perambular com amigos pela cidade, quando se empenha a apreciar o dia a dia dos quartéis. Perscrutar os interiores dos muros e cercas que guardam os homens fardados e a rotina sólida desses lugares é algo para ele ao mesmo tempo curioso e prazeroso. Residir próximo de uma base militar, torna ainda mais fácil a flanerie de Ademir em torno do universo por trás dos muros e outras proteções comuns à caserna.

Um dia, contudo, os garotos que costumam acompanhá-lo roubam uma misteriosa caixa da base militar. No processo de chegarem aos receptores, residências são invadidas, quase todas as pessoas no bairro são presas, muitas são torturadas. Os militares exigem os nomes dos criminosos a todo custo. A fim de se livrarem dos tormentos os amigos de Ademir disseram tê-lo visto nas imediações de onde estava a caixa, não tardou para que ele se tornasse o principal acusado do roubo. Os soldados, então, invadiram a casa do jogador, violentaram suas irmãs, espancaram sua mãe e o levaram preso. Ademir foi torturado até a morte. Sobre esse conto Lidiane Carvalho Nunes, afirma:

Ademir tinha todo o profissionalismo necessário para ser um jogador com destaque mundial, afinal, nunca era parado por nenhum outro jogador dentro de campo, porém, fora dele, foi parado antes do tempo. Um conto policial de ação que se disfarça em um conto de futebol que, por sua vez, trata das fraquezas humanas e dos muros que nos cercam. ${ }^{2}$

\footnotetext{
${ }_{1}^{1}$ GALLO. O gol esquecido: contos de futebol, p. 37.

${ }^{2}$ NUNES. O crime como método: um estudo da literatura policial na obra de Mayrant Gallo, p. 100.
} 
Por sua vez, o conto "Cemitério clandestino", de Ana Paula Maia, faz parte da coletânea Entre as quatro linhas: contos sobre futebol, organizada por Luiz Ruffato, resultante de um projeto que reúne narrativas produzidas por 15 escritores. Todos os contos dessa coletânea de alguma forma dialogam com algum aspecto do futebol. 0 conto de Maia se concentra na preparação e desenvolvimento de uma pelada de rua, jogada por um grupo de garotos, com destaque para o cenário esdrúxulo em que se dá a partida: um cemitério.

\section{APITOS INICIAIS}

Segundo Lígia Bezerra, autora do artigo "Sabiás, macieiras da Califórnia e cadáveres em campos de futebol: imagens do Brasil em três canções do exílio", em um microconto de Fernando Bonassi, intitulado "Canção do exílio", com óbvia intertextualidade com os textos homônimos de Gonçalves Dias e Murilo Mendes, três aspectos ganham destaque: o caos, a violência e a pobreza. ${ }^{3}$ Vejamos o texto de Bonassi:

Minha terra tem campos de futebol, onde cadáveres amanhecem emborcados pra atrapalhar os jogos. Tem uma pedrinha cor-de-bile que faz "tuim" na cabeça da gente. Tem também muros de bloco (sem pintura, é claro, que tinta é a maior frescura quando falta mistura) onde pousam cacos de vidro pra espantar malandro. Minha terra tem $\mathrm{HK}$, AR15, M21, 45 e 38 (na minha terra, 32 é uma piada). ${ }^{4}$

Bezerra direciona sua análise para a desestabilização da cenografia, que progride a partir de um duplo isolamento experimentado pelos habitantes marginalizados nas grandes metrópoles brasileiras: "além de viverem isolados fora dos muros dos condomínios de luxo, eles também são isolados dentro dos seus próprios 'muros altos sem pintura', com cacos de vidro 'pra espantar malandro'”.5

\footnotetext{
3 BEZERRA, Lígia. Sabiás, macieiras da Califórnia e cadáveres em campos de futebol: Imagens do Brasil em três canções do exílio, p. 4.

${ }^{4}$ BONASSI, Fernando apud BEZERRA, Lígia. Sabiás, macieiras da Califórnia e cadáveres em campos de futebol: Imagens do Brasil em três canções do exílio, p. 5.

${ }^{5}$ BEZERRA. Sabiás, macieiras da Califórnia e cadáveres em campos de futebol: Imagens do Brasil em três canções do exílio, p. 41.
} 
Para além desta análise o que nos chama a atenção no micro conto de Bonassi é a relação entre literatura, futebol e violência, com destaque para as aproximações entre as figurações do corpo maltratado ou do cadáver e o campo de futebol, numa relação fundamentalmente distópica e assentada sob a ideia de catástrofe. Esse teor catastrófico, por sua vez, ganha visibilidade em função de três aspectos: no âmbito das escolhas temáticas, a presença dos signos da segregação ou da anomia, que culminam em apartação social; no âmbito da organização estética, a progressão do entusiasmo para a exposição da vulnerabilidade, na medida em que há uma desterritorialização dos afetos positivos, relacionados ao ufanismo no poema de Gonçalves Dias, para em seguida haver a inserção explosiva dos signos da abjeção; no âmbito da estrutura narrativa, a presença da progressão entre o bom lugar e o lugar infernal - no caso do conto de Bonassi, decorrente dos efeitos argumentativos em função do diálogo intertextual com o texto de Gonçalves Dias, na medida em que a paisagem absolutamente ufana (o locus amoenus) do poeta maranhense se torna sujeita à implosão do cenário urbano distópico (o locus terrible), de Bonassi.

Observo que esta organização se faz presente nos dois contos apresentados. Nesse sentido, minha hipótese é a de que mesmo estando no domínio do conto há nas duas narrativas ora uma conjunção, ora uma progressão de circunstâncias que são acompanhadas também por uma conjunção ou progressão estética ao reunir elementos ora voltados ao locus amoenus, o dinamismo (do jogo de futebol) e da alegria (provindas da juventude e infância dos protagonistas) e o locus terrible (evocado na tortura, no assassinato ou ocultamento de corpos).

A propósito, primeiramente, destaco que esta relação se apresenta sempre marcada por um conteúdo trágico. Fernando Stratico dá especial destaque ao fato de o futebol estar sempre próximo à tragédia, talvez porque o futebol seja possuidor da "energia cruel e mortal que habita o rito e a celebração". ${ }^{6}$ Por sua vez, Vitor Lourenço Rodriguez Salgado avalia que o rito do jogo se estrutura sob a mescla identitária que reúne jogadores e torcedores - unidos pelas ideias de

\footnotetext{
${ }^{6}$ STRATICO. O texto abjeto e performativo do futebol e da poesia, p. 75 .
} 
pertencimento e partilha: a alegria, o entusiasmo e a emoção nascem desse casamento. ${ }^{7}$ Havendo nessa relação certamente aquela "energia cruel" de que fala Stratico, que parece estar no rito desde sua formação, permanecendo na performance do jogo.

Dessa forma, o futebol movimenta uma rede de afetos - afins ao rito do jogo e sua performance - da mesma forma que pode fazer explodir uma rede de violências no centro, na margem ou no entorno do lugar onde ocorre. Acerca disto, recorro a Luiz Henrique de Toledo, que afirma em seu artigo "Por que xingam os torcedores de futebol?": "para além de sua prática consubstanciada no esforço físico, destreza e habilidade no trato com a bola por parte daqueles que jogam a fruição do futebol consiste também em uma experiência da ordem do vivido e do falado", 8 que extrapola para o texto literário quando este se encontra atravessado pela triangulação entre literatura, futebol e violência. Nesse processo, não só a linguagem, mas as práticas direcionadas à arena do jogo transcendem “o tempo e o espaço ritualístico do momento de cada partida". ${ }^{9}$ Em outras palavras: estão na vida.

Nessa perspectiva, minha segunda hipótese assenta-se sobre a ideia de que os dois contos em análise consistem em narrativas cujo desenvolvimento problematiza esse caráter especular entre vida e jogo.

\section{PRIMEIRO TEMPO: “ADEMIR”}

Não há mais trens, ao menos para mim. Não há. Não adianta procurar. As linhas estão vazias. As noites correm sem eles. Adelice fala de um trem que ela jamais avistou.

Eu, de um que vi e que passou... É o que pode haver de pior: desaparecer. Primeiro os trens, depois eu, você. 10

Recordações de andar exausto, Mayrant Gallo.

\footnotetext{
${ }^{7}$ SALGADO. Bolas de papel: sociedade, gênero e território em contos de futebol argentinos, p. 39.

${ }^{8}$ TOLEDO. Por que xingam os torcedores?, p. 20. (Grifos do autor).

${ }^{9}$ TOLEDO. Por que xingam os torcedores?, p. 20.

${ }^{10}$ GALLO., p. 98.
} 
Em investigação sobre a representação do esporte na literatura brasileira das décadas de 1910 e 1920, João Carlos Alfredo levanta um conjunto de teorias sobre o futebol. Visto como "texto" que recebe variados tratamentos e cujo caráter ambivalente "sugere sua importância dentro do quadro social brasileiro, enquanto estatuto de interferência no imaginário do cotidiano",11 ao futebol vinculam-se tópicos teorizantes, como a gênese mítica e revolucionária do rito, suas regras e interditos, o valor econômico e simbólico do ídolo futebolístico, o paralelismo entre o rito do esporte e o paradigma da guerra, o autoritarismo do cartola, a cultura da evasão presente na ideia do esporte como show. Em "Ademir", como também no conto "Fiapo", publicado na mesma coletânea, a formação do "ídolo futebolístico" ganha destaque. De fato, podemos pensar a organização da narrativa do conto distribuída em duas partes, respectivamente, a ascensão e a queda do ídolo.

A primeira parte é dedicada a apresentar o protagonista, e, sobretudo, narrar a sua formação como jogador desde o futebol de rua até a conquista de um lugar em um time pequeno, mas que o leva à visibilidade e a despontar como promessa de se tornar ídolo. Nessa etapa, um narrador em terceira pessoa caracteriza Ademir como um jovem habilidoso cujos traços, presentes em seu corpo, se estendem em direção a uma comunidade social e cultural marcada pela vulnerabilidade: "Ademir era negro. Feito do cheiro e da dor das senzalas multiplicadas em favelas e bairros erguidos sobre paus finos em alagados fétidos". ${ }^{12}$ Ao modo reflexivo o narrador em seguida joga com estereótipos comuns à categorização de jogadores identitariamente ligados às condições subalternas: "Atrevido, ria branco dos defeitos dos outros. Dos seus também".13 Ao mesmo tempo em que reordena esses aspectos, trazendo-os, de forma ressignificada para o universo do futebol, a fim de mostrar como Ademir, com formosura e talento, domina o objeto mais amado no jogo de futebol:

Controlava a bola do mesmo modo que alguém movimenta os olhos, sem se dar conta, por um sutil e incompreensível comando que remonta aos primórdios da vida, no borbulhar dos primeiros pântanos. E havia

\footnotetext{
${ }^{11}$ ALFREDO. Futebol, futebóleres: uma representação do esporte na literatura brasileira de 1910 e 1920 , p. 15.

${ }_{12}$ GALLO. O gol esquecido: contos de futebol, p. 37.

${ }^{13}$ GALLO. O gol esquecido, p. 37.
} 
momentos em que a bola e seus olhos, na vastidão verde, assemelhavam-se a um solitário planeta e seus dois satélites. A estranha órbita compunha-se da leitosa parábola rumo ao gol e do percurso de volta, ao meio de campo, por entre corpos adversários batidos e faces cabisbaixas, humilhadas. ${ }^{14}$

Em um dos depoimentos que Mayrant Gallo concedeu a respeito de $O \mathrm{gol}$ esquecido, no decorrer do lançamento da produção, há referências de que tenha se inspirado em amigos e situações da época em que foi atleta para compor vários dos contos da coletânea, a exemplo de "O goleiro que dormiu cedo",15 bem como, nas atuações de celebrados ídolos futebolísticos. Por esse motivo, é possível que a constituição do protagonista do conto aqui analisado remeta, ao modo da "imitação prestigiosa", 16 às performances de Ademir da Guia, o "Divino", ídolo do Palmeiras nascido em 1942, filho de Domingos da Guia, ambos de uma família reconhecida "por implantar o estilo divino e elegante de jogar futebol".17

Desse modo, é possível identificar pelo menos três grandes correspondências. Primeiro, Ademir da Guia, "o jogador sarará que vestia a camisa dez do Palmeiras",18 é afrodescendente, mais propriamente mestiço; Ademir, protagonista do conto, "era negro". Segundo, assim como Ademir da Guia, Ademir insere-se no labor futebolístico através do futebol de rua. Sobre esse aspecto o próprio Ademir da Guia esclarece: "Na realidade comecei na rua até o dia em que eu fui treinar no Bangu e tinha 15 anos. E aí fiquei no Bangu, ${ }^{19}$ comecei a jogar no infantil, no juvenil, foi quando na realidade eu comecei no futebol que era disputando campeonatos. Mas no início foi na rua”. ${ }^{20} 0$ terceiro aspecto diz respeito a um elemento do futebol que reúne tática, estética e potência: o drible. Ou melhor: a pungência que resulta do drible, que é poética ao se comunicar com o público. Segundo Hilário Franco Júnior, "toda partida é uma atividade comunicativa”. ${ }^{21} 0$ drible, como parte da gramática da atividade comunicativa proposta por Franco Júnior, exige a agregação de códigos poéticos ao processo comunicativo a fim de

\footnotetext{
${ }^{14}$ GALLO. O gol esquecido, p. 37.

15 Ver a reportagem "Mundo do futebol inspira livro com 21 histórias de escritor baiano". Disponível em https://glo.bo/34KA1BZ.

${ }_{16}$ MAUSS apud GIGLIO. Análise da construção do ídolo a partir da trajetória de Ademir da Guia, p. 105.

17 GIGLIO. Análise da construção do ídolo a partir da trajetória de Ademir da Guia, p. 105.

${ }_{18}^{18}$ CORREIA. Os Ademires de João Cabral de Melo Neto, p. 38.

${ }^{19}$ Não custa lembrar aqui que o Bangu também esteve presente na juventude de Mayrant Gallo.

${ }^{20}$ DA GUIA apud GIGLIO. Análise da construção do ídolo a partir da trajetória de Ademir da Guia, p. 107.

${ }^{21}$ FRANCO JÚNIOR. A dança dos deuses: futebol, cultura e sociedade, p. 359.
} 
insuflar a emoção de quem o testemunha. O protagonista do conto possui velocidade ("Controlava a bola do mesmo modo que alguém movimenta os olhos"), concentração ("E havia momentos em que a bola e seus olhos, na vastidão verde, assemelhavam-se a um solitário planeta e seus dois satélites") e habilidade ("A estranha órbita compunha-se da leitosa parábola rumo ao gol e do percurso de volta, ao meio de campo, por entre corpos adversários"), ao ponto de ter absoluto domínio da bola e subjugar o adversário.

Contudo, a velocidade, a concentração e a habilidade de Ademir são norteadas pelo ritmo altamente desenvolvido, ritmo que se organiza ao molde dos movimentos de seus olhos, em pelo menos dois momentos do trecho do conto, conforme os destaques, nas citações. Não por acaso, é possível observar esse mesmo ritmo, concentração e habilidade no poema que João Cabral de Melo Neto ${ }^{22}$ compôs para Ademir da Guia (Ritmo líquido se infiltrando / no adversário, grosso, de dentro, / impondo-lhe o que ele deseja, / mandando nele, apodrecendo-o) ${ }^{23}$ e que tem o ritmo como fio condutor de uma "racionalidade impositiva", ${ }^{24}$ ao mesmo tempo em que desponta como principal categoria a estabelecer relações de correspondência entre arte e futebol. ${ }^{25}$

Como suplementos, essas correspondências nuançam e ao mesmo tempo potencializam a ideia de que Ademir, sendo negro e pobre, porém talentoso jogador, tinha tudo para dar certo e, portanto, reforçam o hiato que marcará o fim do herói. Nessa perspectiva, seguramente, a maior diferença entre o protagonista do conto e o inesquecível ídolo palmeirense, reside no destino do atleta da ficção, marcado pela tragicidade da vida interrompida.

Vale ressaltar que a vida interrompida e suas fantasmagorias consistem em temas recorrentes no conjunto da produção de Mayrant Gallo, estando presente também em sua poesia, tal como ocorre com o poema "Fantasma", que se encontra

\footnotetext{
${ }^{22}$ Ademir da Guia também é referido no poema "O olho, a bola", de Vera Casa Nova, e na letra de "Pr'o Esporte", décima segunda canção da sinfonia Paulistana, de Billy Blanco.

${ }_{23}$ MELO NETO. Museu de tudo, p. 28.

${ }^{24}$ CORREIA. Os Ademires de João Cabral de Melo Neto, p. 42.

${ }^{25}$ CORREIA. Os Ademires de João Cabral de Melo Neto, p. 39.
} 
em epígrafe neste tópico. Nele, o trem é uma "extensão do sujeito em construção" 26 em que

O espectro da existência dos trens é a constatação de que há/haverá uma ida sem volta, seja do trem, do sujeito lírico, de Adelice, ou do leitor. Mesmo afastados do trem, ainda prevalece algum tipo de ligação, em especial a ressignificação do que sobra deles. ${ }^{27}$

A reflexão literária de Gallo desloca-se, dessa forma, da tematização acerca das interrupções para a especulação sobre a repetição. Esse mesmo movimento pode ser observado no conto "Ademir". Na progressão da narrativa, Ademir aos poucos é, portanto, apartado do universo de origem, na medida em que se aproxima do brilho da condição de ídolo, o que faz dele alguém "que excede o ordinário e que é amado e querido por aqueles que se deparam com isso". ${ }^{28}$ Entretanto, aí também se instaura, intempestivamente, a queda do ídolo, que norteia a segunda parte da narrativa.

Nessa segunda etapa, ocorrem os acontecimentos terríveis que o tornam presa fácil da ação dos militares e vão levá-lo à morte: a traição dos amigos "talvez por inveja, despeito, intolerância" 29 - que o acusam do roubo que não cometeu, a violação das mulheres de sua família, a tortura que sofre para confessar o crime, por fim, a morte disfarçada na metáfora da interrupção. A narração abarca as condições infames: há uma guinada estética, na medida em que o narrador glosa, por procuração, a linguagem do trauma, para dar conta da agonia vivida pelo protagonista:

Tortura: golpes gravitando em torno. Dor. Escuridão. Abismo. Um súbito descortinar: luz. Os últimos fiapos de um sonho. A multidão que não houve, a vibração suspensa, parada, como se a uma ordem divina a existência se toldasse.

Futebol. Os que não jogam vibram, e até param por isso.

Pararam Ademir. 30

Nesse ponto cabe destacar que o caminho do ídolo se entrecruza com o dos algozes porque Ademir quando "não jogava, rondava pelos arredores, com os

\footnotetext{
${ }^{26}$ SOARES. Alegorias contemporâneas: imagens do pensamento na lírica de Mayrant Gallo e Gonçalo M. Tavares, p. 167.

${ }^{27}$ SOARES. Alegorias contemporâneas, p. 168.

${ }^{28}$ NUNES. O crime como método: um estudo da literatura policial na obra de Mayrant Gallo, p. 191.

${ }^{29}$ NUNES. O crime como método, p. 100.

${ }^{30}$ GALLO. O gol esquecido, p. 39.
} 
amigos, admirando os aviões, as armas, os uniformes". ${ }^{31}$ Ademir não apenas admira, mas também realiza o voyeurismo direcionado à caserna - e nesse processo o fetiche do homem da caserna ou pela vida da caserna, reflete o imperativo viril e civil, impregnado no fetiche enquanto um modelo com o qual o protagonista se identifica.

Nesse processo, a constituição de Ademir enquanto personagem nos lembra o protagonista de Mãos de cavalo, romance de Daniel Galera, narrativa também situada na relação entre literatura, violência e futebol. Tal como no romance o conto de Mayrant Gallo maneja um protagonista ainda muito jovem e em busca de afirmar a virilidade, a bravura, o domínio técnico, a resistência, o heroísmo, índices da respeitabilidade e da autoridade, que o auxilie a sobreviver e a permanecer visível, naquilo que faz de melhor. Assim como Hermano, herói moralmente caído em Mãos de cavalo, neste conto também encontramos "um garoto que deseja firmar-se tal qual a imagem de homem que perpassa o seu imaginário". ${ }^{32}$

Na companhia de Pierre Bourdieu, em A dominação masculina, que Anna Carolina Takeda usa como referência para analisar Mãos de cavalo, tem-se que a "virilidade pode ser entendida como capacidade reprodutiva, sexual e social, mas também aptidão ao combate e ao exercício da violência",33 condições que os fazem reunir-se em determinados espaços de convivência comunitária, onde é possível reconhecerem-se e afirmarem-se: as "casas-dos-homens". Tanto o campo de futebol quanto o quartel podem ser considerados como "casas-dos-homens", lugares culturalmente fixados como espaços por excelência masculinos e onde em geral há uma forte identificação com um mimetismo da violência. ${ }^{34} \mathrm{~A}$ aproximação ao paradigma da guerra; o desenvolvimento de uma determinada técnica; a humilhação, real ou simbólica, do adversário, são alguns dos pontos de contato entre estas "casas-dos-homens". No entrelace entre as duas partes se encontra a aproximação entre ambos, a caserna e o campo de futebol, ponto nevrálgico que leva à devoração do "ídolo futebolístico" que consegue driblar com perfeição a bola, mas não escapa da violência instituída que assola a vida.

\footnotetext{
${ }^{31}$ NUNES. O crime como método, p. 100.

32 TAKEDA. A obsessão pela virilidade em Mãos de cavalo: poder e ruína, p. 154.

33 BOURDIEU apud TAKEDA. A obsessão pela virilidade em Mãos de cavalo, p. 155.

${ }^{34}$ WELZER-LANG apud TAKEDA. A obsessão pela virilidade em Mãos de cavalo, p. 155.
} 
Portanto, na transição que o personagem faz ao ir do campo de futebol para os arredores da base militar, há uma relação de espelhamento ou de continuidade entre dois territórios afinados com um projeto de virilidade, que se torna ao mesmo tempo objeto de desejo e de perecimento do herói, condição que leva o conto, em sua culminância, à associação entre trauma, abjeção e tragicidade.

\section{SEgundo TEMPO: “CEMitÉRIo ClANDESTINO”}

No descomeço era o verbo.

Só depois é que veio o delírio do verbo. O delírio do verbo estava no começo, lá onde a criança diz: Eu escuto a cor dos passarinhos.

A criança não sabe que o verbo escutar não funciona para cor, mas para som. Então se a criança muda a função de um verbo, ele delira. E pois. Em poesia que é voz de poeta, que é a voz de fazer nascimentos - 0 verbo tem que pegar delírio.

O livro das ignorãças, Manoel de Barros.

Além de fazer parte da coletânea Entre as quatro linhas: contos sobre futebol, o conto "Cemitério clandestino" pode ser encontrado, na íntegra, na coletânea Histórias de Bolso: 21 contos de autores lusófonos anotados por estrangeiros, disponível na Plataforma on line Wook.pt. ${ }^{35} 0$ conto de Ana Paula Maia integra, também, o Suplemento do Jornal da UNESP, publicado em junho de 2014, onde pode ser apreciado em conjunto com a tela "Futebol" (1935), de Cândido Portinari, em um belo editorial de divulgação da coletânea Entre as quatro linhas: contos sobre futebol, que conta também com uma entrevista do organizador Luiz Ruffato.

De acordo com a fortuna crítica do conjunto da produção de Ana Paula Maia até o momento, os procedimentos e as representações pulp, a extraordinária precarização e perversão da existência, o investimento temático e especulativo acerca do "homem-besta", ${ }^{36}$ consistem nas linhas de força de sua escrita. A

\footnotetext{
${ }^{35}$ Disponível em: https://bit.ly/2PLKetW.

${ }^{36}$ Ver, por exemplo, DAPUZZO. Liberdade e absurdo em Carvão animal, de Ana Paula Maia (2018); BARBERENA. A hipercontemporaneidade ensanguentada em Ana Paula Maia (2016); MEIRELES. Rinhas de humanos: violência e negação de cidadania em Entre rinhas de cachorros e porcos abatidos, de Ana Paula Maia (2015).
} 
narrativa do conto em tela não está descolada dessas insígnias, talvez por isso mesmo constituindo-se como um bom exemplar do manejo do abjeto.

A narrativa conta como, durante um belíssimo fim de tarde, quando "[...] as sombras acobertam parte do dia e o sol recua alguns metros atrás das montanhas", ${ }^{37}$ sete meninos sobem a rua e, sem saber, pulam o muro de um cemitério clandestino "que para eles é só um terreno com espaço suficiente para jogarem futebol sem serem incomodados".38

A introdução dos elementos de abjeção que pululam por toda a narrativa os "ossos ressequidos",39 o "saco de ossos",40 ou em outro momento, "crânios partidos, antebraços, fêmures, mandíbulas, costelas" 41 e, por fim, uma mandíbula guardada em uma sacola - acomodam-se à linguagem próxima da prosa poética, da mesma forma que a referência intertextualizante ao número sete (o que nos faz imediatamente lembrar dos sete anões da famosa narrativa infantil), e, também, à abertura pontuada por uma diluição do espaço e do tempo à maneira das fábulas infantis, logo substituída por índices, ou melhor, por iluminações, de lugar e de tempo: são crianças que enfrentam vulnerabilidades em função do local que habitam, barracos "em meio à escassez, à poeira e ao fedor"; 42 há um cemitério clandestino; ao fim da pelada os meninos testemunham uma situação de evidente "desova" 43 de ossos em uma cova rasa; na culminância da narrativa tem-se a busca de um menino de fora do time pelos supostos restos mortais do pai desaparecido.

No estudo já citado Futebol, futebóleres, João Carlos Alfredo, apoiado em Carlos Byngton, enfatiza os pés como um signo fundamental no jogo de futebol, ressaltando-lhes uma função simbólica associada a "processos inconscientes e vegetativos", o que possibilita atribuir ao futebol uma resposta revolucionária "exatamente por reintroduzir a parte inferior do corpo, tão reprimida pela cultura e relacioná-la com o centro". ${ }^{44}$

\footnotetext{
${ }^{37}$ MAIA. Cemitério clandestino, p. 113.

${ }^{38}$ MAIA. Cemitério clandestino, p. 113.

${ }^{39}$ MAIA. Cemitério clandestino, p. 114.

${ }^{40}$ MAIA. Cemitério clandestino, p. 114.

${ }^{41}$ MAIA. Cemitério clandestino, p. 115.

${ }^{42}$ MAIA. Cemitério clandestino, p. 113.

${ }^{43}$ No português falado no Brasil, mais propriamente como parte do jargão policial, "desova" corresponde ao ato de ocultar um cadáver.

${ }^{44}$ BYNGTON apud ALFREDO. Futebol, futebóleres, p. 16-17.
} 
Como a chuva referida pelo narrador, que "haverá de revelar o que está escondido",45 "Cemitério clandestino" parece dialogar exatamente com esse caráter desencobridor, associado aos pés no jogo de futebol, uma vez que é na demanda do espaço mais adequado para a pelada, um bom lugar para rolar a bola, que os sete meninos encontram-se com ossos (ainda) escondidos nos armários da História e, desse modo, todo um arquivo residual acerca da violência urbana na periferia das grandes metrópoles brasileiras vem à tona, na forma de ossos ressequidos, de mortos sem identificação ou identidade. Talvez, por isso, o narrador reflita, em tom de crítica à evasão, que mesmo sem conhecerem o que habita debaixo dos seus pés os sete meninos "Gostam de estar entre os mortos. Desses mortos. Sem nome, idade ou passado que os identifiquem". ${ }^{46}$

O cemitério e a clandestinidade se encontram, portanto, também nesse intervalo entre literatura, violência e futebol. Dessa forma, no conto de Maia temos mais uma vez aquela mesma organização estética, anteriormente observada, cuja base reside no trânsito entre o locus amoenus, aqui representado pelo movimento e graciosidade da pelada jogada por sete meninos; e, o locus terrible, constituído pelo cenário e também pela presença de elementos de abjeção, relacionados ao assassinato e ocultação de cadáveres.

No Brasil, o arquivo residual acerca dos cemitérios clandestinos traz referência imediata ao uso desses espaços como recurso final para o acobertamento de crimes cometidos por traficantes ou milicianos, como o cemitério descoberto no Parque Sarandi, em agosto de 2019, ${ }^{47}$ localizado na cidade de Queimados, região metropolitana do Rio de Janeiro, que continha ossos enterrados de três pessoas desconhecidas. Ou ainda o cemitério clandestino de Embu das Artes, na região metropolitana de São Paulo, ${ }^{48}$ onde, até o momento, foram encontrados 12 cadáveres. A outra referência sem dúvida vai de encontro ao período ao estado de exceção, instaurado no país, em 1964, e que tem o Cemitério Clandestino de Perus, atualmente conhecido por Colina dos Mártires, como exemplo mais conhecido: Perus foi usado para a "desova" dos corpos de desaparecidos políticos, no interior

\footnotetext{
${ }^{45}$ MAIA. Cemitério clandestino, p. 114.

${ }^{46}$ MAIA. Cemitério clandestino, p. 114.

47 Disponível em: https://glo.bo/2MhmcVt.

${ }^{48}$ Disponível em: https://bit.ly/2tHNpdp.
} 
da maquinaria da repressão desempenhada pelo braço policial do regime civil e militar de 1964.

Uma série de acontecimentos absurdos, todavia, colados à realidade, ${ }^{49}$ se encontram, portanto, sintetizados em um cenário: o desse cemitério, clandestino, onde as crianças brincam como se não fossem espreitadas de perto pelo terror e pelos caminhos que levam à morte violenta. A narrativa do conto nos mostra um tempo semelhante ao tempo do Transuerpiel benjaminiano, em que o presente mira o passado e sua forma de apropriá-lo é através dos resíduos que este nos lega: suas sucessivas catástrofes. Nesse sentido, os pés que chutam a bola - e os ossos - no cemitério clandestino, realizam uma espécie de catarse, mas também um acerto de conta com questões relacionadas às diversas formas de violência na cultura brasileira, pois, na medida em que movimenta a triangulação de referências históricas e culturais esforça-se em realizar a crítica da repetição. Essa reflexão igualmente se evidencia em "Ademir".

Dessa forma, ambos os contos se encontram atravessados por essa crítica da repetição seja pela encruzilhada das duas "casas-dos-homens" presentes no conto de Mayrant Gallo - e armadilha fatal para o futebolista de sucesso, mas que nunca deixou de carregar as marcas da subalternidade, seja em razão da inocência das crianças a brincarem sobre os ossos ressequidos do cemitério clandestino. Esse cemitério - os muitos cemitérios clandestinos ao longo de uma história da catástrofe - localiza-se fundamentalmente em um contexto de violações onde não deve haver inocentes, pois no universo da infância (in-fans) a inocência representa "um Inconsciente, ou seja, a um saber que não se sabe, a um saber sem sujeito", 50 como pondera Giorgio Agamben.

Por último, com igual realce, portanto, faz-se presente uma crítica da distração, que dialoga diretamente com a crítica da repetição, presente nos dois contos, seja pelo encantamento de Ademir pela caserna, no conto de Mayrant Gallo, seja pela inocência das crianças no conto de Ana Paula Maia. Talvez por isso, em sua finalização, a narrativa do conto "Cemitério clandestino" indique tanto a

\footnotetext{
${ }^{49}$ Vale ressaltar que é nesse prisma direcionado ao "mundo real", tão ou até mais absurdo do que a própria ficção, que reside o grande flerte do conto com as representações pulp, com as quais a produção de Maia dialoga.

${ }^{50}$ AGAMBEN. Infância e história, p. 70.
} 
possibilidade de um acerto de contas com um passado violento, quanto a perspectiva do mergulho na distração:

Em casa, a bola agora limpa, resplandece numa prateleira.

0 menino adormece olhando para ela, sonhando com um futuro promissor, sonhando com a partida do dia seguinte. Na casa ao lado, a mandíbula, ao lado de outros pedaços de ossos, resplandece numa prateleira. 0 menino adormece enquanto olha para ela, sonhando com esse pedaço de osso. ${ }^{51}$

Assim, ambos os contos especulam também sobre a contínua atualização de um paradigma necropolítico baseado em exclusão. A força policial e militar representa bem isso em "Ademir". Em relação ao conto de Maia, com base no raciocínio de Agamben e considerando toda a carga residual da repetição, é possível especular que se a inocência da criança representa o "saber sem sujeito", por sua vez, o acéfalo diante do horror corresponde a um sujeito-sem-saber e por isso mesmo distraído, preso no intervalo entre a sideração e a letargia. 0 sujeitosem-saber não está na dimensão do Inconsciente, mas da Indiferença que abraça por ingenuidade ou oportunismo.

Esse argumento presente nas entrelinhas de "Cemitério clandestino" dialoga de perto com o poema de Manoel de Barros, em epígrafe, um poema que penetra fundo na ideia da criança como "saber sem sujeito" associada a uma alegoria do fazer artístico, produto de um delírio da (na) linguagem, nascido no entrelace entre o descomeço e o reúso, que leva a outro conhecimento e intrínseco a ele a possibilidade de recomeçar ou remodelar uma experiência: reinvenção. Em um belo ensaio sobre esses aspectos na poesia de Manoel de Barros, Nismária Alves David observa que no "[...] movimento cíclico em que se encontra a infância o poeta resgata a origem do ser e do poético",52 para que possa resgatar "os valores de liberdade, já perdidos por causa da força da razão e do tempo linear, ou seja, é quem retorna à origem mítica e imanentemente lúdica". ${ }^{53}$ A infância representa, desse modo, igualmente o retorno à origem que permite "[...] um novo nascimento,

\footnotetext{
${ }^{51}$ MAIA. Cemitério clandestino, p. 115.

52 DAVID. "Avançar para o começo": o mito na poesia de Manoel de Barros, p. 136.

53 DAVID. "Avançar para o começo", p. 137.
} 
místico, espiritual, o qual conduz à possibilidade de renovar e regenerar a existência daquele que empreende sua busca". ${ }^{54}$

O delírio agasalha-se, portanto, no verbo (na palavra) fazendo-o delirar. Esse exercício poético-conceitual, metapoético, me leva a pensar que o delírio também circunscreve a escrita de Maia, uma escrita que estando na ordem do abjeto clama pela reinvenção das formas-de-vida: ao fazerem o reúso do cemitério, das ossadas ora roladas em conjunto com a bola de futebol. Bola e ossada transformadas em souvenires que resplandecem em prateleiras de casas onde o único bem material e a única coisa bonita para ser admirada é uma bola de futebol, 55 as crianças trazem para a escrita do conto esse absurdo da realidade que se revela, por correspondência, tão ou mais absurdo que a ficção e, sobretudo, a necessidade de reinventá-la.

\section{PRORROGAÇÃo - ATÉ A PRóXIMA PARTIDA}

Além da concentração em situações e cenários relacionados ao mundo do futebol, a violência é, obviamente, o outro aspecto saliente em ambos os contos. Naquele produzido por Gallo, a violência vem na forma da violação dos corpos, violação cotejada das mais diversas maneiras: sequestro, apreensões indevidas, estupro, espancamentos, tortura, assassinato. A primeira parte concentra-se nas habilidades futebolísticas e nas promessas de ascensão do protagonista, na alegria que circunda o jogo de futebol. A segunda parte, como já referido, é toda encaixada na abjeção.

Atravessado por singularidades relativas à infância e também a um cenário social e cultural muito marcado pela experiência extremófila o conto de Maia se encaixa no rol dos textos literários que elaboram uma crítica à violência e, sobretudo, ao escuro da vida: as dimensões do Mal, na medida em que ao trazer a mistificação para o texto - a mistificação da inocência, a mistificação do jogo desmistifica determinados aspectos obscurecidos pela relativização ou

\footnotetext{
54 DAVID. "Avançar para o começo", p. 137.

${ }^{55}$ MAIA. Cemitério clandestino, p. 113.
} 
sacralização do uso. Nesse sentido, trata-se de uma literatura que encontra sua dicção com a filosofia, no âmbito da profanação.

Profanar é resistir. Por esse motivo, finalizo este artigo com uma deferência a Giorgio Agamben, para quem a "passagem do sagrado ao profano pode acontecer também por meio de um uso (ou melhor, de um reúso) totalmente incongruente do sagrado", 56 algo que em ambos os contos se faz pela via da associação entre a infância e a morte, entre o lúdico (o jogo) e o sombrio e catastrófico (a existência de cemitérios clandestinos), capazes de evocar o insólito da situação apresentada, porque, afinal, é a dimensão insólita da situação que institui um rasgo na liturgia do jogo, representado pelo futebol.

\section{REFERÊNCIAS}

ALFREDO, João Carlos. Futebol, futebóleres: uma representação do esporte na literatura brasileira de 1910 e 1920. Dissertação (Mestrado). Programa de Pós-Graduação em Teoria Literária, Instituto de Estudos da Linguagem, Universidade Estadual de Campinas, 1996.

AGAMBEN. Giorgio. Infância e história. Belo Horizonte: UFMG, 2005.

AGAMBEN, Giorgio. Elogio da profanação. In: Profanações. Tradução de Selvino José Assmann. São Paulo: Boitempo, 2007.

BARROS, Manoel de. O livro das ignorãças. Rio de Janeiro: Record, 2001.

BEZERRA, Lígia. Sabiás, macieiras da Califórnia e cadáveres em campos de futebol: Imagens do Brasil em três canções do exílio. Lucero, 20, 2010, 33-46.

CORREIA, Éverton Barbosa. Os Ademires de João Cabral de Melo Neto. Aletria, Belo Horizonte, v. 26, n. 3, p. 33-48, 2016.

DAMO, Arlei. A magia da seleção. Revista Brasileira de Ciências do Esporte, v. 28, n. 1, p. 73-90, 2006.

DAVID, Nismária Alves. "Avançar para o começo": o mito na poesia de Manoel de Barros. Ipotesi, UFJF, Juiz de Fora, v. 9, p. 135-146, 2005.

FRANCO JÚNIOR, Hilário. A dança dos deuses: futebol, cultura e sociedade. São Paulo: Cia. das Letras, 2007.

${ }^{56}$ AGAMBEN. Elogio da profanação, p. 66. 
GALLO, Mayrant. Recordações de andar exausto. Salvador: Aboio Livre Edições, 2005.

GALLO, Mayrant. Ademir. In: . O gol esquecido: contos de futebol. São

Paulo: A girafa, 2014, p. 37-39.

GIGLIO, Sérgio Settani. Análise da construção do ídolo a partir da trajetória de Ademir da Guia. Oralidades, n. 7, jan.-jun. 2010, p. 101-124.

MAIA, Ana Paula. Cemitério clandestino. In: RUFFATO, Luiz (org.). Entre as quatro linhas: contos sobre futebol. São Paulo: DSOP, 2013, p. 113-115.

MELO NETO, João Cabral de. Museu de tudo. Rio de Janeiro: José Olympio Editora, 1975.

NUNES, Lidiane Carvalho. O crime como método: um estudo da literatura policial na obra de Mayrant Gallo. Dissertação (Mestrado). Universidade Estadual de Feira de Santana, Feira de Santana, 2014.

SALGADO, Vitor Lourenço Rodriguez. Bolas de papel: sociedade, gênero e território em contos de futebol argentinos. Dissertação (Mestrado). Universidade Federal do Rio de Janeiro, Rio de Janeiro, 2018.

SOARES, Marcela Rodrigues. Alegorias contemporâneas: imagens do pensamento na lírica de Mayrant Gallo e Gonçalo M. Tavares. Tese (Doutorado). Instituto de Letras da Universidade Federal da Bahia, Salvador, 2018.

STRATICO, Fernando. O texto abjeto e performativo do futebol e da poesia. Aletria, 2012, maio-ago, n. 2, v. 22.

TAKEDA, Anna Carolina Botelho. A obsessão pela virilidade em Mãos de cavalo: poder e ruína. Estação Literária, v. 6, p. 153-164, 2016.

TOLEDO, Luiz Henrique de. Por que xingam os torcedores? Cadernos de Campo, São Paulo, n. 3, 1993. 